\section{TÀI LIÊU THAM KHẢO}

1. Elnagar, Mohammed \& Aronovich, Sharon \& Kusnoto, Budi. (2019). Digital Workflow for Combined Orthodontics and Orthognathic Surgery. Oral and Maxillofacial Surgery Clinics of North America. 32. 10.1016/j.coms.2019.08.004.

2. Swennen, Gwen \& Mollemans, Wouter \& Schutyser, Filip. (2009). Three-Dimensional Treatment Planning of Orthognathic Surgery in the Era of Virtual Imaging. Journal of oral and maxillofacial surgery: official journal of the American Association of Oral and Maxillofacial Surgeons. 67. 2080-92. 10.1016/ j.joms. 2009.06.007.

3. Scolari, Neimar. (2013). Three-dimensional Planning in Orthognathic Surgery using Cone-beam Computed Tomography and Computer Software. Journal of Computer Science \& Systems Biology. 06. 10.4172/0974-7230.1000127.

4. Ortes, Faruk \& Cansiz, Erol \& Arslan, Yunus Ziya. (2019). Computer-Aided Design of SubjectSpecific Dental Instruments for Preoperative Virtual Planning in Orthognathic Surgery. 10.1007/978-3030-13951-3_4.
5. Zavattero, Emanuele \& Romano, Michele \& Gerbino, Giovanni \& Rossi, Diego \& Giannì, Aldo \& Ramieri, Guglielmo \& Baj, Alessandro. (2019). Evaluation of the Accuracy of Virtual Planning in Orthognathic Surgery: A Morphometric Study. The Journal of craniofacial surgery. Publish Ahead of Print. 10.1097/SCS.0000000000005355.

6. Shaheen, Eman \& Coopman, Renaat \& Jacobs, Reinhilde \& Politis, Constantinus. (2018). Optimized 3D virtually planned intermediate splints for bimaxillary orthognathic surgery: A clinical validation study in 20 patients. Journal of Cranio-Maxillofacial Surgery. 46. 10.1016/j.jcms.2018.05.050.

7. Conley, R. \& Edwards, Sean. (2018). Threedimensional treatment planning for maxillary and mandibular segmental surgery for an adult Class III: Where old meets new. The Angle Orthodontist. 89. $10.2319 / 120117-823.1$.

8. Sylvester, David \& Sullivan, Steven. (2019). Virtual Surgical Planning (VSP): Current Concepts in Orthodontics and Oral and Maxillofacial Surgery. 10.1007/978-3-030-00722-5_12.

\title{
TÌM HIỂU MỐI LIÊN QUAN CỦA TÌNH TRANG NHIỄM HPV VớI CÁC TRIÊ̂U CHỨNG LÂM SÀNG, CÂN LÂM SÀNG CỔ TỬ CUNG TẠI BỆNH VIÊ̂N PHỤ SẢN HẢI PHÒNG
}

\section{TÓM TẮT}

Chỉ định cắt tử cung hoàn toàn hay bán phần trong u xơ tử cung căn cứ vào nhiều yếu tố trong đó có kết quả xét nghiệm HPV. Mục tiêu: Tìm hiểu mối liên quan của tình trang nhiếm HPV với các triệu chứng lấm sàng, cân lâm sàng cổ tử cung tại Bênh viện Phụ sản Hải Phòng. Đối tượng và phướng pháp nghiên cứu: 420 bệnh nhân thực hiện sàng lọc ung thư cổ tử cung tại Bệnh viện Phụ sản Hải Phòng từ tháng 6/2019 đến tháng 12/2019 tạai Bệnh viện Phụ sản Hải Phòng. Kết quả: Tỳ lệ nhiếm HPV nguy cơ cao gây ung thư cổ tử cung là $7,1 \%$. Tỷ lệ có tổn thương cổ tử cung ở nhóm HPV dương tính cao gấp 1,7 lần nhóm không tổn thương cổ tử cung $(p=0,12)$. Tỷ lệ nhiễm HPV ở nhóm có soi cổ tử cung bất thường gấp 2,21 lần nhóm soi cổ tử cung bình thường ( $p=$ 0,04). Tỷ lệ nhiễm HPV của nhóm có tế bào học cổ tử cung bất thường gấp 9,2 lần nhóm có tế bào học bình thường $(p=0,004)$. Kết luân: Tỷ lệ nhiễm HPV là $7,1 \%$. Tỷ lệ nhiễm HPV ở nhóm có soi cổ tử cung bất thường cao hơn nhóm soi cổ tử cung bình thường ( $p$ $=0,04)$. Tỷ lệ nhiễm HPV của nhóm có tế bào học cổ tử cung bất thường cao hơn nhóm có tế bào học bình thường $(p=0,004)$.

\section{*Bênh viên Phu sản Hải Phòng}

Chịu trách nhiếm chính: Lưu Vũ Dũng

Email: Luuvudung1980@gmail.com

Ngày nhận bài: 26.11.2020

Ngày phản biện khoa học: 28.12.2020

Ngày duyệt băi: 8.01.2021
Lưu Vũ Dũng*

Từ khóa: soi cổ tử cung, HPV Cobas,ung thư cổ tử cung

\section{SUMMARY \\ THE RELATIONSHIP BETWEEN HPV INFECTION AND CLINICAL, SUB-CLINICAL SYMPTOMS CERVICAL IN HAI PHONG HOSPITAL OF OBSTETRIC AND GYNECOLOGY}

Indications of complete hysterectomy or partial hysterectomy due to Uterine Leiomyoma base on many factors, one of them is HPV testing. Objectives: To study the relationship beetwen HPV infection and clinical, subclinical symptoms in HaiPhong Hospital of obstetric and gynecology. Subjects and methods: 420 patients who havecervical screening from 6/2017 to 6/2019 Hai Phong Hospitalof Obstetrics and Gynecology. Results: The rate of high-risk HPV infection causing cervical cancer was $7.1 \%$. The prevalence of cervical lesions was 1.7 times higher in the positive group of HPV without the cervical lesions $(p=0.12)$. The prevalence of HPV in abnormal colposcopy group was 2.21 times higher than that of normal colposcopy $(p=0.04)$. The prevalence of HPV in abnormal cervical cytology group was 9.2 times higher than the group with normal cytology ( $p=0.004)$. Conclusions: The prevalence of HPV infection is $7.1 \%$. The rate of HPV infection in group with abnormal colposcopy is higher than that of normal colposcopy $(p=0.04)$. The HPV infection rate of the group with abnormal cervical cytology is higher than the group with normal cytology $(p=0.004)$.

Keywords: colposcopy, HPV Cobas, cervical cancer 


\section{I. ĐẶT VẤN ĐỀ}

Ung thư cổ tử cung (UTCTC) là bênh lý ác tính của biểu mô lát (biểu mô vảy) hoặc biểu mô tuyến cổ tử cung, thường gặp từ độ tuổi 30 trở đi, đứng hàng thứ hai trong các ung thư sinh dục ở nữ giới về tỷ lệ mắc cũng như tỷ lệ tử vong [1]. Năm 2018, tỷ lệ mắc mới ung thư cổ tử cung là $7,1 / 100.000$ phụ nữ và có xu hướng gia tăng theo năm. Ung thư cổ tử cung không xảy ra đột ngột mà diễn tiến một cách âm thầm trong nhiều năm, gây nên những biến đổi bất thường ở tế bào cố tử cung, các tổn thương tiền ung thư rồi đến ung thư, kéo dài trung bình từ 10 - 15 năm. Tầm soát ung thư cổ tử cung là tìm ra ung thư trước khi những triệu chứng lâm sàng biểu hiện ra bên ngoài [2].

Hiện nay, quy trình sàng lọc ung thư cổ tử cung gồm: khám lâm sàng cổ tử cung, soi cổ tử cung với dung dịch acid acetic (VIA), xét nghiệm Thinprep PAP và xét nghiệm ADN HPV.

Xuất phát từ thực tế trền, chúng tôi tiến hành nghiên cứu: "Tìm hiếu mối liên quan của tình trạng nhiếm HPV với các triệu chứng lấm sàng, cận lâm sàng cổ tử cung tại Bệnh viện Phụ sản Hải Phòng ".

II. ĐỐI TƯợNG VÀ PHƯƠNG PHÁP NGHIÊN CỨU

2.1. Đối tượng nghiên cứu; Đối tượng nghiên cứu: 420 bênh nhân được khám sàng lọc ung thư cổ tử cung tại Bệnh viện Phụ sản Hải Phòng.

- Thời gian nghiên cứu: từ tháng 6/2019 đến tháng 12/2019.

- Tiêu chuấn lứa chon:

+ Phụ nữ đã có quan hệ tình dục.

+ Hiện tại không có thai.

+ Không thụt rửa âm đạo trước khi xét nghiệm.

+ Không đặt thuốc điều trị phụ khoa trước đó ít nhất 7 ngày.

+ Khi xét nghiệm không trong thời kỳ hành kinh.

- Tiêu chuấn loai trứ:

+ Không có đầy đủ các thông tin nghiên cứu.

+ Đã chẩn đoán ung thư cổ tử cung trước đó.

\subsection{Phương pháp nghiên cứu}

2.2.1.Thiêt kếnghiên cứu: nghiên cứu mô tả cắt ngang.

\subsubsection{Chỉ số nghiên cứu:}

- Kết quả khám lâm sàng cổ tử cung

- Kết quả soi cổ tử cung

- Kết quả xét nghiệm Thinprep Pap (tế bào học)

- Kết quả xét nghiệm HPV (thực hiện trên máy Cobas 480 hãng Roche)

\subsection{Quy trình thực hiện:}

- Bệnh nhân đến khám phụ khoa sàng lọc UTCTC tại Bênh viện Phụ sản Hải Phòng được thực hiện: khám lâm sàng cổ tử cung, soi cổ tử cung, xét nghiệm Thinprep PAP, xét nghiệm HPV.

- Ghi nhận các thông tin vào bảng thu thập số liệu sẵn có.

- Xử lý và phân tích số liệu.

2.4. Xử lý số liệu: Dựa trên phần mềm SPSS22.0.

2.5. Đạo đức nghiên cứu: Các thông tin cá nhân đều được đảm bảo giữ bí mật. Nghiên cứu nhằm mục đích đóng góp vào việc bảo vệ và nâng cao sức khỏe. Đề tài đã thông qua hội đồng khoa học Bệnh viện Phụ Sản Hải Phòng.

\section{KẾT QUẢ NGHIÊN CỨU}

3.1. Tỷ lệ nhiễm virus HPV ở nhóm nghiên cứu

- Tỷ lệ nhiễm virus HPV

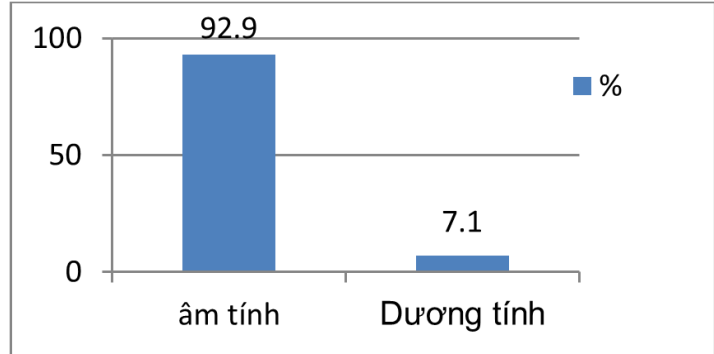

Biểu đồ 1. Tỷ lệ nhiễm HPV dương tính của đôi tượng nghiên cứu

Nhận xét: Đa số bệnh nhân có tỷ lệ HPV âm tính chiếm tỷ lệ $92,9 \%$. Tỷ lệ nhiễm HPV có nguy cơ gây ung thư cổ tử cung là $7,1 \%$.

3.2. Mối liên quan giữa tình trạng nhiễm HPV với các triệu chứng lâm sàng, cận lâm sàng trong sàng lọc ung thư cổ tử cung

3.2.1. Môi liến quan giữa tình trạng nhiếm HPV với tình trạng khám lâm sàng cổ tử cung

Bảng 3.1. Liên quan giữa tình trạng nhiễm HPV với tình trạng khám lâm sàng cổ tử cung

\begin{tabular}{|c|c|c|c|c|}
\hline HPV Khám lâm sàng & $\begin{array}{c}\text { Tốn thương } \\
\mathbf{n}(\%)\end{array}$ & $\begin{array}{c}\text { Bình thường } \\
\mathbf{n}(\%)\end{array}$ & $\begin{array}{c}\text { OR } \\
\text { KTC 95\% }\end{array}$ & $\mathbf{p}$ \\
\hline Dương tính & $18(9,2)$ & $12(5,4)$ & 1,7 & 0,12 \\
\hline Am tính & $178(90,8)$ & $212(94,6)$ & $(0,83-3,8)$ & 0,12 \\
\hline
\end{tabular}

Nhận xét: Ơ̛ nhóm sàng lọc HPV dương tính nhận thấy: tỳ lệ có tốn thương cố tứ cung và không tổn thương cổ tử cung lân lượt là $9,2 \%$ và $5,4 \%$. Nhóm có cổ tử cung tổn thương có tỷ lệ nhiễm HPV gấp 1,7 lần nhóm không tổn thương nhưng sự khác biệt này không có ý nghĩa thống kê với $p=0,12$. 
Bảng 3.2. Liên quan giữa tình trạng nhiễm HPV với kêt quả soi cổ tử cung

\begin{tabular}{|c|c|c|c|c|}
\hline SPV Soi cố tử cung & $\begin{array}{c}\text { Bất thường } \\
\text { n (\%) }\end{array}$ & $\begin{array}{c}\text { Bình thường } \\
\text { n (\%) }\end{array}$ & $\begin{array}{c}\text { OR } \\
\text { KTC 95\% }\end{array}$ & p \\
\hline Dương tính & $20(66,7)$ & $10(33,3)$ & 2,21 & 0 \\
\hline Ám tính & $185(41,4)$ & $205(52,6)$ & $(1,01-4,85)$ & 0,04 \\
\hline
\end{tabular}

Nhận xét. Tỷ lệ nhiễm HPV ở nhóm có soi cố tử cung bất thường gấp 2,21 lần nhóm soi cố tử cung bình thường với KTC $95 \% 1,01-4,85$. Sự khác biệt này có ý nghĩ thống kê với $p=0,04$

Bảng 3.3. Liên quan giữa tình trạng nhiếm HPV với kêt quả xét nghiệm Thiprep PAP (tế bào hoc)

\begin{tabular}{|c|c|c|c|c|}
\hline HPV Thinprep PAP & $\begin{array}{c}\text { Bất thường } \\
\text { n (\%) }\end{array}$ & $\begin{array}{c}\text { Bình thường } \\
\mathbf{n}(\%)\end{array}$ & $\begin{array}{c}\text { OR } \\
\text { KTC 95\% }\end{array}$ & p \\
\hline Dương tính & $2(6,7)$ & $28(93,3)$ & 9,2 & 0,004 \\
\hline Ám tính & $3(0,8)$ & $387(99,2)$ & $(1,4-57,4)$ & 0,0 \\
\hline
\end{tabular}

Nhận xét: Trong nhóm tế bào học bất thường tỷ lệ nhiêm HPV là $6,7 \%$. Tỷ lệ nhiếm HPV của nhóm có tế bào học cổ tử cung bình thường gấp 9,2 lần nhóm có tế bào học bất thường, sự khác biệt này có ý nghĩa thổng kê với $\mathrm{p}=0,004$.

\section{BÀN LUÂN}

4.1. Tỷ lệ nhiễm HPV ở nhóm nghiên cứu. Xét nghiệm HPV tại Bệnh viện Phụ sản Hải Phòng được thực hiện trên hệ thống Cobas Z480 tự động của hã̉ng Roche Diagnostic đã được Cơ quan Quản lý Thuốc và Dược phẩm của Hoa Kỳ (FDA) và Cộng đồng chung Châu Âu (CE) phê chuẩn xây dựng thành quy trình sàng lọc UTCTC theo tiêu chuấn Mỹ. Trong số 420 trường hợp nghiên cứu, kết quả ghi nhận tỷ lệ nhiễm HPV là $7,1 \%$ với 30 trường hợp dương tính HPV (biểu đồ 3.1). Theo các nghiên cứu được công bố tại Viêt Nam, tỷ lê nhiểm HPV dao đônng từ 0,9\% đển $19,97 \%$ cho thấy tỷ lệ nhiễm HPV trong nghiên cứu này là thấp hơn kết quả của Bùi Diệu [3], Cao Minh Chu [4], Lê Quang Vinh [5] nhưng kết quả này cao hơn nghiên cứu của Nguyễn Vũ Quốc Huy [2]... Có sự khác biệt này là do khác nhau về đối tượng nghiên cứu, địa điểm thực hiện tại cộng đồng hay bệnh viện, tuổi phụ nữ và vùng miên khác nhau; lối sống, hành vi tình dục với nhiều người, điều kiên kinh tế xã hội ở các địa phương hoắc có thể do phương pháp xác định nhiễm HPV, nhưng nhìn chung, tỷ lệ nhiễm HPV tại Việt Nam dao động khoảng $10 \%$ và phù hợp với tình hình nhiếm HPV ở các nước đang phát triển như phân tích tổng quan của Denny năm 2006 [6], kết quả phân tích của Baseman[7] và Chamot [1] ở phụ nữ trên toàn Thế giới.

4.2. Mối liên quan giữa tình trạng nhiễm HPV với các triệu chứng lâm sàng, cận lâm sàng trong sàng lọc ung thư cổ tử cung

- Liên quan giứa tinh trang nhiếm HPV với tình trạng khám lâm sảng cổ tử cung: Từ kết quả Bảng 3.1, ở nhóm sàng lọc HPV dương tính nhận thây: tỷ lệ có tổn thương cổ tử cung cao gấp 1,7 lần nhóm không tổn thương cổ tử cung (lần lượt là 9,2\% và 5,4\%) nhưng sự khác biệt này không có ý nghĩa thống kê với $\mathrm{p}$ $=0,12$. Có 224 trường hợp cổ tử cung bình thường chiếm 53,3\%; có 196 trường hợp có tổn thương cổ tử cung chiếm $46,7 \%$, đây là những trường hợp được ghi nhận khi khám bằng mắt thường. Theo tác giả Lâm Đức Tâm (2017) [8] thực hiện đề tài tại Thành phố Cần Thơ thì tî lệ khám và phát hiện cổ tử cung bình thường là $73,22 \%$; tỉ lệ phát hiện cổ tử cung bất thường là $26,78 \%$. Kết quả nghiên cứu này có tỉ lệ cổ tử cung bình thường cao hơn nhiều so với nghiên cứu của chúng tôi. Điều này được giải thích là do các đối tượng nghiên cứu của tác giả được chọn ngẫu nhiên của danh sách phụ nữ Cần Thơ theo phương pháp tỷ lệ dân số cộng dồn và phần lớn phụ nữ tham gia đều không có các dấu hiệu bất thường, do đó tỉ lệ bất thường của tác giả thấp hơn nhiêuu so với nghiên cứu của chúng tôii.

- Liên quan giứa tinh trạng nhiếm HPV với kêt quả soi cổ tử cung. Soi cổ tử cung là phương pháp hữu ích để xác định, đánh giá các tổn thương ở cổ tử cung, đặc biệt là các tổn thương tân sản nội biểu mô (CIN). Soi cổ tử cung cho phép quan sát tổn thương được phóng đại ở tại vị trí tổn thương, nơi diển ra các tổn thương nghi ngờ, tiến trình ung thư cổ tử cung. Chỉ định soi cổ tử cung không giống nhau ở từng nước, từng khu vực, thậm chí tại các trung tâm y tế của một nước. Nhiều nước đang phát triển có chỉ định rộng rãi bao gồm cả những đối tượng có nguy cơ thấp ung thư cổ tử cung. Ở các nước phát triển, soi cổ tử cung được thực hiện định kì 6 tháng đến 2 năm và duy trì̀ soi cổ tự cung nếu như có tổn thương nghi ngờ [8]. Trong nghiên cứu này toàn bộ 420 đối tượng tham gia nghiên cứu đều được thực hiện soi cổ tử cung. Cổ tử cung được coi là bình thường khi biểu mô vảy trong suốt, trơn láng, màu hồng nhạt, không 
thay đổi khi bôi acid acetic [8]. Tổn thương lộ tuyến có hình ảnh "chùm nho" sau khi bôi acid acetic hoặc có thể thấy hình ảnh Polyp tuyến cổ tử cung với hình thái bình thường (polype tuyến hoặc có dị sản vảy bình thường trên mặt polype) là những tổn thương lành tính. Nghiên cứu này, chúng tôi phân loại tổn thương cổ tử cung thành thành từng nhóm cổ tử cung lành tính và cổ tử cung bất thường để dễ so sánh với tỷ lệ nhiễm HPV. Thông qua bảng 3.2 cho thấy: Tỷ lệ nhiễm HPV ở nhóm có soi cổ tử cung bất thường gấp 2,21 lần nhóm soi cổ tử cung bình thường với KTC $95 \%$ 1,01- 4,85. Sự khác biệt này có ý nghĩ thống kê với $p=0,04$. Tương tự nghiên cứu của Cung Thị Thu Thủy (2012) tại Bệnh viện Phụ sản Trung Ương khi soi cổ tử cung ở phụ nữ có tế bào cổ tử cung bất thường, HPV dương tính ở nhóm phụ nữ có kết quả soi cổ tử cung bất thường là $62,4 \%$ tăng lên $100 \%$ khi soi nghi ngờ ung thư cổ tứ cung.

- Liên quan giữa tình trang nhiễm HPV với kêt quả xét nghiệm Thiprep PAP (tê" bào hoc). Thinprep Pap Test có nhiêu ưu điểm vượt trội như làm tăng độ nhạy và độ đặc hiệu trong phát hiện các tế bào tiền ung thư', đặc biệt là các tế bào biểu mô tuyến, một loại tế bào ung thư rất khó phát hiện. Theo các nghiên cứu, phương pháp Thinprep giúp tăng $55 \%$ số phát hiện tế bào nguy cơ ung thư cao so với phương pháp Pap truyền thống. Phương pháp Thinprep đồng thời mang lại sự cải thiện rõ rệt về tính đồng đều tế bào trong công đoạn lấy mẫu, giúp viêc phát hiên các tốn thương tế bào tiền xâm nhập trong các nhóm bệnh nhân tới khám tại bệnh viện, cũng như kết quả sàng lọc trong cộng đồng. Trong nghiên cứu của chúng tôi ở Bảng 3.3: Tỷ lệ nhiễm HPV của nhóm có tế bào học cổ tử cung bình thường gấp 9,2 lần nhóm có tể bào học bất thường, sự khác biệt này có ý nghĩa thống kê với $p=0,004$. Trong nghiên cứu này, tỷ lệ Thinprep PAP bất thường là $1,2 \%$. Kết quả này thấp hơn so với nghiên cứu của Cao Minh Chu[4], trong đó 4,9\% được xác định là Thinprep PAP bất thường, thấp hơn so với nghiên cứu của Nguyễn Vũ Quốc Huy[2] trên 1139 phụ nữ 15-49 tuổi đã có chồng tại Thừa Thiên-Huế (Thinprep PAP dương tính là 6,3\%). Như vậy có thể thây kết quả sàng lọc UTCTC tại cộng đồng bằng phương pháp tế bào học của chúng tôi khác so với các tác giả khác và với các nghiên cứu khác nhau thì tỷ lệ PAP dương tính rất khác nhau, nguyên nhân có thể do cách lựa chọn đối tượng nghiên cứu, đô tuổi của các đối tượng nghiên cứu khác nhau nền có thể dẫn đến tỷ lệ PAP dương tính cũng khác nhau. Mặt khác, do tập quán, lối sống, tình trạng kinh tế xã hội, ý thức của mỗi vùng, mỗi quốc gia cũng khác nhau. Thêm vào đó, kinh nghiệm sàng lọc của các tác giả cũng rất khác nhau và nó có ảnh hưởng nhất định đến kết quả sàng lọc. Việc đọc kết quả xét nghiệm PAP phụ thuộc rất nhiều vào kinh nghiệm của bác sĩ giải phẫu bệnh.

\section{KẾT LUÂ̂N}

Tỷ lệ nhiễm HPV nguy cơ cao gây ung thư cổ tử cung là $7,1 \%$. Tỷ lệ nhiễm HPV ở nhóm có soi cổ tử cung bất thường gấp 2,21 lần nhóm soi cổ tử cung bình thường $(p=0,04)$. Tỷ lệ nhiễm HPV của nhóm có tế bào học cổ tử cung bình thường gấp 9,2 lần nhóm có tế bào học bất thường $(p=0,004)$.

\section{KHUYẾN NGH!}

Ung thư cổ tử cung là bệnh nguy hiểm nhưng có thể làm giảm tử vong và gánh nặng cho gia đình và xã hội nếu được phát hiện sớm và điêuu trị kịp thời. Cần khuyến cáo phụ nữ nên đi khám sàng lọc ung thư cổ tử cung định kì để có thể phát hiện sớm và điều trị kịp thời các tổn thương CTC nhằm giảm tỷ lệ ung thư.

\section{TÀI LIÊU THAM KHẢO}

1. Chamot E, Kristensen S, Stringer J SA., Mwanahamuntu M, (2010), "Are treatments for cervical precancerous lesions in less developed countries safe enough to promote scaling of cervical screening programs? A systematic rewiew", BMC Women's Health, 10, pp.11. doi: 10.1186/1472- 6874-10-11.

2. Nguyễn Vũ Quốc Huy, (2014), "Xét nghiệm HPV trong sàng lọc ung thư cổ tử cung: Cập nhật 2014", Tạp chí Phụ Sản, tập 12, số 2, tr. 08- 14.

3. Bùi Diệu, Vũ Thị Hoàng Lan và cộng sự, (2010), "Tình hình nhiếm HPV tại Hà Nội", Tạp chí Ý học thực hành- Bộ Y tế, số 745- số 12/2010, tr. 5-6.

4. Cao Minh Chu, Lê Trung Thọ, (2013), "Nghiên cứu tỷ lệ nhiêm Human Papilloma virus ở phụ nữ Cân Thớ và một số yếu tố liên quan", Tạp chí Y hoc Thực hành, Bộ Y tế, 875, tr. 41- 44 .

5. Lề Quang Vinh, Pham Thị Thanh Yên, Nguyễn Khánh Dương, Lê Hoàng Linh, Đào Duy Quânn và cộng sự, (2015), "Nghiên cứu tỷ lệ nhiểm Human Papilloma virus ở cán bộ nữ Bệnh viện Phụ Sản Trung ương", Tap chí Phụ Sản, Tập 13,(2), tr. 9-11

6. Denny L, Quinn M, Sankaranarayanan R, (2006), "Chapter 8: Screening for cervical in developing coutries", Vaccine, 24S3, pp. S3/71- S53/77.

7. Baseman J.G, Koutsky L.A, (2005), "The epideminology of Human Papilloma virus infection", Journal of Clinical Virology, 32S, pp. 16- 24.

8. Lâm Đức Tâm (2017), "Nghiên cứu tỷ lệ nhiễm Human Papilloma virus, một số yếu tố liên quan và kết quả điêu trị các tốn thương cổ tử cung ở phụ nữ Thành phố Cần Thơ", Luân văn Tiến sỹ Y học, Trường Đại học Y - Dược Huế. 